\title{
RESPONDING TO ISLAMOPHOBIA BY INTERNALIZING THE VALUE OF ISLAM RAHMATAN LIL ALAMIN USING THE MEDIA
}

\author{
Muhamad Parhan ${ }^{1 *}$, Mohammad Rindu Fajar Islamy ${ }^{2}$, Nurti Budiyanti ${ }^{3}$, \\ Risris Hari Nugraha ${ }^{4}$, Pandu Hyangsewu ${ }^{5}$ \\ ${ }^{1}$ Indonesia University of Education, Bandung, Indonesia, e-mail:parhan.muhamad@upi.edu \\ ${ }^{2}$ Indonesia University of Education, Bandung, Indonesia, e-mail: fajarislam2000@upi.edu \\ ${ }^{3}$ Indonesia University of Education, Bandung, Indonesia, e-mail:nurtibudiyanti@upi.edu \\ ${ }^{4}$ Indonesia University of Education, Bandung, Indonesia.e-mail: risrisharinugraha@upi.edu \\ ${ }^{5}$ Indonesia University of Education, Bandung, Indonesia.e-mail: hyangsewn@upi.edu \\ *Corresponding Author
}

\begin{abstract}
(c) (i) (2)
(C)2020 by the authors. Submitted for possible open access publication under the terms and conditions of the Creative Commons Attribution-ShareAlike 4.0 International License-(CC-BY-SA) (https://creativecommons.org/licenses/by-sa/4.0/) do) DOI : http://dx.doi.org/10.30983/islam realitas.v6i2.3695
\end{abstract}

\begin{tabular}{l|l|l} 
Submission: 12 November 2020 & Revised: 19 December 2020 & Published: 31 December 2020
\end{tabular}

\begin{abstract}
This article focuses on an inaccurate understanding of Islam that causes hatred, anxiety, and unfounded fear of the Muslim community. On account of this view of Islam, Muslims face hostility, discrimination, intolerance, and racism. This attitude is increasingly seen in mass media propaganda that presents a partial and inaccurate view of the religion. Islam is presented as a violent belief system and is responsible for radicalism and terrorism. The media greatly influences social reality. They function as a spectacle, but they also influence public opinion on a range of issues. The research design of this paper uses literature review with descriptive analysis. The results show that internalizing the Islamic value of rahmatan lil alamin ("being a mercy to the world") through the media is a solution that can rectify misconceptions about Islam. Along with the foundation of amar ma'ruf nabi munkar ("enjoining the good and forbidding the evil"), the value of "being a mercy to the world" can transform people into educators (muaddib), agents of correct information (musaddid), reformers (mujaddid), unifiers (muwabhid), and fighters (mujabid).
\end{abstract}

Keywords: Islamophobia; Media; Internalization; Islam rahmatan lil alamin.

\begin{abstract}
Abstrak
Artikel ini fokus terhadap pemahaman Islam dengan perspektif yang salah, sehingga menimbulkan kebencian, kecemasan, dan ketakutan yang tidak berdasar serta berlebihan kepada individu maupun komunitas Islam. Akibatnya timbul permusuban, diskriminasi, intoleransi, dan rasisme. Sikap ini semakin terlihat melalui propaganda media massa yang menampilkan kontroversi yang tidak benar dan parsial terhadap Islam, media merepresentasikan Islam dengan kekerasan dan radikal melalui fenomena terorisme. Kehadiran media sangat berpengarub terhadap realitas sosial yang tidak. hanya berfungsi sebagai tontonan tetapi menjadi tuntunan yang menggiring opini publik dalam merubah sikap, pandangan, dan perilaku. Desain penelitian menggunakan literature review dengan analisis deskriptif. Hasil penelitian menunjuk.kan bahwa Internalisasi nilai-nilai Islam rahmatan lil alamin melalui media merupakan solusi dalam meluruskan pemahaman yang keliru tentang Islam, yang berfungsi sebagai pendidik (muaddib), agen informasi yang benar (musaddid), menjadi pembaharu (mujaddid), pemersatu (muwabhid), dan pejuang (mujabid) dengan dasar amar ma'ruf nabi munkar.
\end{abstract}

Kata Kunci: Islamophobia; Media; Internalisasi; Islam rahmatan lil alamin

\section{Background}

Islam is a religion that teaches what to believe (aqidab), how to worship (syariah), and how to deal with other people in a public context muamalah. ${ }^{1}$ It is oriented towards the benefits and happiness of people in this world and in the hereafter. ${ }^{2}$ Islam is revealed to establish the universal teaching of rabmatan lil alamin, or mercy for the world, including human
${ }^{1} \mathrm{C}$ Nasuha, 'Konsep Islam dalam Pemikiran ISIF', Jurnal Islam Indonesia, 1.1 (2009), 1-8.
${ }^{2}$ Muhammad Turmudi, 'Produksi dalam Perspektif Ekonomi Islam', Islamadina, XVI (2017), 37-56. 
beings and all forms of life. ${ }^{3}$ This implies that Islamic teachings is inclusive of all humanity. ${ }^{4}$ It is a perfect system without any shortcomings. It teaches human beings sound and authentic knowledge about divine revelation ${ }^{5}$ that is relevant for all time and place (salib li-kulli zaman wa-makan). ${ }^{6}$ Islam is manifested in the form of attitudes and behaviors that are based on Islamic values to direct the human being towards achieving happiness in this world and the Hereafter. ${ }^{7}$

The presence of Islam is able to transform human beings into a tolerant, humanistic, peaceful. and prosperous social creature. ${ }^{8}$ This is based on the values of ilabiyyah (Godlihood) and value insaniyyah (humanity). ${ }^{9}$ This is expressed by embracing people, rather than hitting them, approaching them rather than avoiding them, inviting them rather than mocking them. Islam appeals to the conscience, not through harsh words. It is evident that the birth of Islam is the foundation of social life in order to create religious harmony. This has been proven since the pre-Islamic time to the Hilmiyab time marked by the rise of science and technology. ${ }^{10}$

The media is not only a spectacle but also takes the role of being a guide in life. Media is an important instrument in disseminating ideas and thoughts, which are accessible to anyone and anytime, and the media can strengthen the relationship between people without needing to be bound by place, distance, space, and time ${ }^{11}$. The media should be used as a strategic means for Muslims to spread and strengthen good moral teachings that is the essence of the faith. However, this has been rejected by people who oppose Islam and spread hatred and fear against uslims (Islamophobia). ${ }^{12}$ This attitude is increasingly visible and is being propagated and internalized through mass media. ${ }^{13}$

One of the causes of Islamophobia is the representation of Islam as a violent religion, by focusing on the phenomena of terrorism, ISIS, and Wahabism. The source of this im ${ }^{14}$ age is, of

9 Ahmad Fauzi, "Konstruksi Pendidikan Islam

${ }^{3}$ Muhammad Makmun Rasyid, 'Islam Rahmatan lil Alamin Perspektif KH. Hasyim Muzadi', Epistemé: Jurnal Pengembangan Ilmu Keislaman, 11.1 (2016), 93-116 <https://doi.org/10.21274/epis.2016.11.1.93-116>.; Khabibi Muhammad Luthfi, 'Islam Nusantara: Relasi Islam dan Budaya Lokal', SHAHIH : Journal of Islamicate Multidisciplinary, $\quad 1.1 \quad$ (2017), $\quad 1-18$ <https://doi.org/10.22515/shahih.v1i1.53>.;Muhamma d Harfin Zuhdi, 'Visi Islam Rahmatan lil 'Alamin: Dialektika Islam dan Peradaban', Akademika Jurnal Pemikiran Islam, $53.9 \quad$ (2017), 149-70 <https://doi.org/doi.org/10.1017/CBO978110741532 $4.004>$.

${ }^{4}$ Miftah Mucharomah, 'Guru di Era Milenial dalam Bingkai Rahmatan lil Alamin', Edukasia Islamika, 2.2 (2017), 172 <https://doi.org/10.28918/jei.v2i2.1667>.

${ }^{5}$ Rasyid.

'Irwan Masduqi, "Deradikalisasi Pendidikan Islam Berbasis Khazanah Pesantren", Jurnal Pendidikan Islam, 2.1 (2013),

$1-20$

$<$ https://doi.org/10.14421/jpi.2013.21.1-20>.

Muhamad Parhan and others, 'Internalization Values of Islamic Education at University', International Journal of Psychosocial Rehabilitation, 24.8 (2020), 14778-91 <https://doi.org/10.37200/IJPR/V24I8/PR281455>.

8 Zainudin, 'Kajian Tentang Toleransi Beragama dalam Surat Al-Kafirun', Jurnal Dakwah, X.1 (2009), 1931.; Rasyid. 'Islam Rabmatan lil Alamin Perspektif KH. Hasyim Muzadi', Epistemé: Jurnal Pengembangan Ilmu Keislaman, 11.1 (2016), 93-116.
Berbasis Rahmatan lil"alamin; Suatu Telaah Diskursif", At- Ta"lim: Jurnal Pendidikan, 4.2 (2018), 122-39 $<$ https://doi.org/10.36835/attalim.v4i2.58>.

${ }^{10} \mathrm{~A}$ M Ismatulloh, 'Metode Dakwah dalam AlQur'an (Studi Penafsiran Hamka terhadap QS. An-Nahl: 125)', Lentera, IXX.2 (2015), 155-69 <https://doi.org/http://dx.doi.org/10.21093/lj.v17i2.4 38>.; Luqman Hakeem Frank Wilkins, Pragathesh Batumalai, and Kamarul Azmi Jasmi, 'Media Sosial dan Dampak Positif Menurut Islam', Prosiding Seminar Sains Teknologi dan Manusia 2019, 2019.

11 Hajah Jawiah Dakir, 'Asas Pembentukan Islamiyyat: Jurnal Antarabangsa Pengajian Islam; International Journal of Islamic Studies, 17 (1996), 3-18.; Ismail A'dawiyah, 'Konsep Keluarga Berkualiti Menurut Islam', Al-Hikmah, 2011, 121-44; Jaapar Nur Zahidah and Azahari Raihanah, 'Model Keluarga Bahagia Menurut Islam', Jurnal of Fiqh, 8.2 (2011), 20.

12 Gabriele Marranci, 'Multiculturalism, Islam and the Clash of Civilisations Theory: Rethinking Islamophobia', Culture and Religion, 5.1 (2004), 105-17 <https://doi.org/10.1080/0143830042000200373>.

${ }^{13}$ M Ruthven, 'Islam in the Media. In Interpreting Islam', Sage: In Interpreting Islam, 2012, 51-75 <https://doi.org/https://doi.org/10.4135/9781446217 467.n4;>.

14 Keluarga Menurut Perspektif Al-Quran dan Al-Sunnah', 
course, mass media. ${ }^{15}$ Mass media exists in the midst of a social reality that is full of various interests, conflicts, and situations that are complex and varied. Eriyanto explains that, from a critical perspective, the media is a tool used by dominant groups of society to manipulate and reinforce its agenda while marginalizing weaker groups. ${ }^{16}$

This study uses a literature review method by making a summary, analysis, and conducting a critical and in-depth synthesis of the articles reviewed. The nature of this research is a descriptive analysis that describes the results of the studies obtained. Then the results are further interpreted to offer a deeper understanding of the phenomena concerned.

Through this article, we attempt to reconstruct the true understanding of Islam, one that is aware of the vision of revelation, in order to counter the narrative of people who fear, hate, and discriminate against Muslims (Islamophobia). This is done by articulating the values of Islam as "a mercy for the world" (rahmatan lil alamin) through mass media.

\section{Islamophobia: Definition, History, and Consequence}

Islamophobia is an attitude that shows intolerance to Islam in general and an excessive fear of its presence in the public space. ${ }^{17}$ Barker states that Islamophobia is a form of intolerance towards religious people; it is which is a new form of racism or cultural racism. ${ }^{18}$ More specifically, it is a shutter ${ }^{19}$ who say that fear and hatred against Islam and Muslims. Here it is clearly seen that there is a form of discrimination and intolerance to Muslims all over the world, which is actualized through certain actions and treatment in public spaces. Obviously, this is an attitude of racism.

The language of Islamophobia has two root words, namely Islam and phobia (excessive fear). The term is defined as an unnatural prejudice or fear of Islam and the Muslims, or any attitudes and actions that indicate dislike to the religion of Islam. Islamophobia also has anti-Islamic and anti-Muslim sentiments and anxiety and fear of Islam and Muslim culture. ${ }^{20}$ Thus there is a social rejection to the individual who is a Muslim. ${ }^{21}$ This leads to acts of discrimination and violence against Muslims. ${ }^{22}$ In addition, there are prejudices and negative stereotype about Islam that is brought into the public space through a set of attitudes and discourses that are full of fear of Islam or Muslims, who are considered dangerous enemies. ${ }^{23}$ Islamophobia refers to the act of having unfounded hostility against Islam, which results in discrimination against Muslims in academic, social, economic, cultural and political affairs. ${ }^{24}$ The consequences are the

20 B. Erik, 'Defining and Researching Islamophobia.', Middle East Studies Association of North America (MESA) Is Collaborating with JSTOR to Digitize, Preserve and Extend Access to Review of Middle East Studies, $46.2 \quad$ (2012), 180-89 <https://doi.org/https://doi.org/10.1017/s002631840 $0054146>$.

21 V. Geisser, La Nouvelle Islamophobie (Paris: La Découver, 2003), p. 122

${ }^{22}$ Stolzjörg, 'Explaining Islamophobia. A Test of Four Theories Based on the Case of a Swiss City', Swiss Journal of Sociology, 31.3 (2005), 547-661.

${ }^{23} \mathrm{~J}$. P. Zúquete, 'The European Extreme-Right and Islam: New Directions?', Journal of Political Ideologies, 13.3 (2008), 321-44.

${ }^{24}$ López.

\footnotetext{
9.2 (2007),
$<$ https://doi.org/10.1080/10999940701382607>.

${ }^{19}$ Junaid Rana, 'The Story of Islamophobia', Souls,

<https://doi.org/10.1080/10999940701382607>.

$148-61$
} Racism, London and Atlantic Highlands (NJ: Zed Books, 1997), p. 186-187. 
unfair treatment of Muslims and their societal exclusion from all areas of public life.

Islamophobia as a sociocultural phenomenon existed since the prophetic times. The roots of the Islamophobia appeared in the seventh century when the Prophet Muhammad began his mission. He was treated with resentment, isolation, scorn, and was opposed by the pagan Meccans, who did not like the existence of new religions such as Islam that replaced the religion of their ancestors. ${ }^{25}$ At that time, hostility to Islamic teachings and Muslims appeared amid the Arab nation from which the Prophet Muhammad originated. ${ }^{26}$

When the Prophet first came with his Islamic teachings, the Quraysh tribe opposed and hindered the spread of Islam. They feared the coming of a new power that would reign to replace the values that already existed in their society. Given these historical roots, it is possible that the current phenomenon of Islamophobia expresses the fear of nonMuslims towards Islamic values that is capable of governing civilization and social life. Because of this people hate and fear of Islam excessively, because there is a feeling of losing against Islam. $^{27}$

Islamophobia is a new term that was deliberately made (neologism). It was introduced during the $1970 \mathrm{~s}^{28}$ and became popular for anti-racist activists in Europe in the 1980s and 1990s. In 1997, Islamophobia as a term $^{29}$ was used in the article, "Islamophobia: A Challenge for Us All." ${ }^{30}$ Since then, it became more popularly used by the rest of the world since $9 / 11^{31}$. The tragedy was carried out by terrorism and Islamic extremists. Al-Qaeda is said to be responsible for the terrible attacks. ${ }^{32}$ This further worsened the image of Islam in the world, because Al-Qaeda is affiliated with the religion of Islam. However, it is incorrect to generalize about Muslims. They right term is to just call them "terrorists".

After the tragedy, war against terrorism was waged, and the Islamic community seemed to be an important issue to talk about. The Islamic community is seen as the cause of all the problems and stereotypes and they were subjected to many accusations. ${ }^{33}$ Consequently, the term War Without Borders, global war on Terrorism and counter-terrorism became used. ${ }^{34}$ Islamophobia spread and was rapidly received. It became a new source of common prejudice and hatred toward Islam. The impact of Islamophobia is not only in discrimination but also in the verbal and non-verbal violence committed against Muslims in the world ${ }^{35}$. This is because Islamophobic people consider Islam as an inferior religion that is a threat against the dominant values of global society. ${ }^{36}$ Of course, this is an erroneous view, because it attributes a homogeneous view to a heterogenous and diverse Islamic community.

As a result of this, Islamophobia occurs in various forms of discrimination both physically and verbally, which renders Muslim populations into an oppressed and marginal state. A real example is the case of discrimination of the Uyghur ethnic minority in China and the Rohingya in Myanmar. The history of Islamic

32 Moordiningsih.

33 A. Kuswaya, Melawan Islamophobia Penerapan Tema Qurani tentang Wasatbiyyah Kasus di Maroko dan Indonesia. (Jawa Tengah: Kekata Grup, 2020), p. 2.

${ }^{34}$ Pradipta, C.

35 H. Mahamdallie, Islamophobia: The Othering of Europe's Muslims (UK: Cambridge Univiersity Press, 2015), p. 113.

36 H. Z. Abdel, 'Islamophobia...A Threat....A Challenge', Paper, Published on International Conference on Muslim and Islam in 21st Century: Image and Reality, Kuala Lumpur, International Islamic University of Malaysia, 2004, p.75. 
civilization in China can be traced back to the Tang dynasty (618-907 CE). It was marked by the increasing interaction through Arab and Persian merchants who stayed in the ports of China. Other sources also mention that during the period of 147 years from the year 651 to 798 $\mathrm{CE}$, the Arab states sent messengers more than 37 times to China. ${ }^{37}$ This proves that the Chinese people have known or at least have been interacting with Muslims since the 7th century CE. In addition, this historical evidence also shows that the spread of Islam in China was done peacefully not by way of warfare like the spread of Islam in the Middle East, Africa, and parts of Europe at that time.

The people's Republic of China is one of the oldest countries in the world. The country, established in $221 \mathrm{BCE}$, has the world's largest population of diverse ethnic groups, including the ethnic Uyghur Muslims. This ethnic minority is located in Xinjiang, the westernmost region of China. The Uighurs are Turks; thus, they are physically, culturally, religiously, and linguistically distinct from Chinese people. During Chinese rule, the Uyghur people were always repressed. The change of leadership in China did not bring better conditions for the Uyghur people. In fact, the new system of government implements policies that places a lot of pressure against them.

After the Republican government collapsed, the government of China was taken by the communists by establishing the People's Republic of China. The communist government made Xinjiang a province with some autonomy on September 30,1955, under the name of the Uyghur Xinjiang Autonomous Region. Although Xinjiang became an autonomous region, they did not gain the rights of autonomy. The communist government's efforts to advance the economy in Xinjiang gave more prosperity for the settler communities. This led to a large gap between the indigenous peoples and migrants. Under the Communist government, religious people also suffered pressure under this repressive policy, not excluding the Uyghur Muslims in Xinjiang.

Through the Strike hard policy in 1997, the Chinese government sentenced thousands of Uyghur ethnic Muslims to death in Xinjiang. From then on, China has reached the highest position in human rights abuses. ${ }^{38}$ The crime that befell upon the Uyghur Muslims in China has led to genocide and ethnic cleansing, because it is systematically conducted, beginning with the policies of the Chinese government. Genocide is a very serious crime against humanity. It is an "extraordinary crime" as described in the provisions of the Statute of Romans 2002.

Not only did the Chinese government enact repressive policies in 2015, it also a rule that should not be used by Muslims in the Xinjiang region. The Chinese government prohibits the usage of the burka for Muslims in Urumqi. In 2016 the Chinese government banned Xinjiang Muslims from fasting during Ramadan and forbade all forms of religious activities in schools. In 2017, the Chinese government forbade parents in Xinjiang from naming their children Muhammad, Jihad, Imam, Saddam, and other names.

As for the ethnic Rohingya Muslims, they are one of 135 ethnic minorities in Myanmar. They are considered as the most persecuted ethnic group according to the UN. Ethnic Rohingya Muslims have been discriminated against since 1948 when the British enacted a policy of ethnic separation. This policy, which was carried out in the Rakhine region, separated the ethnic Burmese from the Rohingya Muslims. Under the military rule of BurmaMyanmar there emerged in 1982 a new policy called the Burma Citizenship Law (BCL). In this

38 N. Kurniawan, Nasib Etnis Minoritas Robingya (Kuala Lumpur: Pusat Informasi dan Advokasi Rohingya, 2012), p. 133 
law, the Rohingya citizens was denied citizenship, land rights, and education and decent and adequate employment ${ }^{39}$.

There are about 1.4 million Rohingya Muslims scattered around the world. The majority of them reside in Burma, followed by Bangladesh and Pakistan. Once known as Muslim citizens of Arakan, the Muslim Rohingya people have lived in the Rakhine region for more than 500 years. Initially, the Rohingya Muslims lived separately when the Burma-Myanmar people were colonized by the British in the 1780s, followed by Japanese occupation in World War II, before finally becoming an independent state and was eventually governed by the military Junta era.

Since Burma-Myanmar's independence in 1948, Rohingya Muslims are continuously being oppressed and not recognized as part of the 136 ethnic Burma-Myanmar. However, historically, they have settled in Arakan since the 7th century CE, long before the Burma-Myanmar state was established in 1948. The Rohingya ethnic group, especially since the 1940s, is always experiencing suppression, murder, torture, rape, and discrimination by the government and fellow residents of different ethnic and religious groups. Many Rohingya ethnicities are not recognized as Burmese-Myanmar citizens. ${ }^{40}$

The threat of violence against the ethnic minority of different religions by the majority Buddhists population is due to the discriminatory policy applied by the government. The Burmese-Myanmar military government adopted a policy of forced assimilation and did not recognize ethnicity as part of the Burmese-Myanmar nation. ${ }^{41}$

Based on the report by Amnesty International, the forms of the cruelty

39 Kurniawan.

40 Kurniawan.

41 A. Pramono, Peran UNHCR dalam Menangani Pengungsi Myanmar Etnis Robingya di Bangladesh (Periode 1978 -2002) (Jakarta: Universitas Indonesia., 2010), p. 47.

${ }^{42}$ Benjamin Zawacki, 'Amnesty: Muslim Rohingya

Terus Alami Kekerasan', Report (Jakarta, 2012) committed by the military Junta against Rohingya Muslims are among others: 1) refusal to grant citizenship; 2) restriction of movement; 3) limitation of economic activity; 4) limitation of education; 5) Murder, detention, and torture; 6) harassment of women and marriage restrictions; 7) allowing anti-Muslim riots to occur. The Amnesty International researcher Benyamin Zawacki in 2012 stated that "it has been too long the record of human rights in Burma-Myanmar to be stained, which is due to the absence of citizenship rights to ethnic Rohingya Muslims and also the ongoing discrimination given against them" ${ }^{42}$. Zawacki's opinion is not unwarranted. The BurmeseMyanmar military government in 1988 through the State Peace and Development Council (SPDC) implemented a burmanisation policy. SPDC argues that burmanization is not the same as the communalization because ethnic Burmese are the ethnic majority whereas cultures and religions that are not derived from Burma-Myanmar are foreign religions and cultures.

Also, there are other discriminatory treatments conducted by the government other than not recognizing the citizenship of Rohingya Muslim. They are also do not recognize economic rights; they forced the change of names of Islamic historical places; and they claim ethnic Rohingya Muslims are ethnically Bengalis. The government's main motivation suppress Rohingya Muslims is to prevent diasporic Rohingya Muslims from returning to Burma-Myanmar. ${ }^{43}$

\section{The Role of the Media from the Islamic viewpoint}

The scholars of Muslim history who study the Prophet Muhammad's mission divide the

<https://www.bbc.com/indonesia/dunia/2012/07/120 720_burma_new>.

43 D. Levinson, Ethnic Relations: A Cross Cultural Encyclopedia (Santa Barbara: ABC-CLIO Inc, 1994), p. 171. 
era into two phases: The first is the period of alistid'af (oppressed condition); the second is the period of al-tamkin (strong condition). The period of al-istid'af is defined by the scholars as a condition where the Muslims were not able to apply Islamic law (shari'a) because of the opposition from the enemy. ${ }^{44}$ As for the condition of al-tamkin, it is the opposite of the concept of istid'af, in that the Muslims were able to freely express their faith. The tamkin period is aligned with the ever-changing era of change. ${ }^{45}$

There are many factors that restrict the Muslims freedom of movement, one of which is when they are the minority population. The consequences that this minority Muslim must accept are the various forms of discrimination such as bullying, torture, entry into prison, or even exile on an island. ${ }^{46}$ A contemporary scholar, Ziyad bin 'Abid, examines some key factors of the occurrence of al-istid'af among Muslims, such as blind fanaticism to ethnic groups, colonial rule, and ideological war. ${ }^{47}$ The efforts that must be fulfilled by Muslim leaders to ward off discriminatory actions against minority Muslims should include strengthening the faith of Muslims, strengthening Muslim fighters, improving the economy, strengthening political action, strengthening the media, strengthening the unity of Muslims, and raising jihad in the path of God.

The media has a huge influence in spreading Islamophobia in various parts of the world. The media often portray Islam as an anarchist, radical, and primitive religion. This is an image that will cause global fear and hatred against Islam. Historical facts note that the media can be used not only to raise awareness of religious issues, but to deal with other issues, such as politics, war, and others. Thus the role of media is considered very urgent and crucial for the realization of a victory. Napoleon Bonaparte, a popular general commander once argued: "In fact, non-material or intangible factors in warfare, are more important and dangerous than material factors with a comparison of three versus one." 48

The non-material factor in question is Napoleon's media war to shift the public opinion about war. Victory in war between two enemies depends heavily on the psychological factors of his soldiers. A highly motivate soldier with a strong sense of optimism will increase the fighting power in everyone else. Conversely, when anxiety, fear, and pessimism overtake the soldiers, then they are already half defeated.

The importance of the media is something that is not ignored by the Prophet Muhammad. The Hudaybiyya Treaty is one of the examples of the use of this method. In signing the treaty, the Prophet tried to use public opinion to weaken the opposing forces and break the unity between them. ${ }^{49}$

The use of the media is crucial in order for Muslims to effectively disseminate true Islamic values to all humankind. Muslims should engage in the media war by countering any accusation by the opposing parties based on real data. This strategy was done by the Prophet Muhammad, who eradicated the distribution of hoax news that was spread by the Meccan pagan Ka'ab ibn al-Ashraf and Asma Bint Marwan. These figures are known to have spread fake news to provoke the pagan Quraysh into fighting the Islamic state (daulah Islamiyyah) ${ }^{50}$.
${ }^{44}$ N. M. Jād, Al-Ta'āmul ma'a ghair Al-Muslimin fi Al'Abdi Al-Nabawì (Cairo: Dār al-Maymān, th), p. 103.

45 Khālid bin Sulaimān. Al-Fahdāwī, Al-Fiqh AlSiyāsì li Al-Watsāiq Al-Nabawiyyah (Urdun: Dār AlAmmār, 1995), p. 23-33.

46 Z. Abid, Al-Istid'äf wa Ahkeamubu fi Al-Figh AlIslāmī (Riyādh: Dār Kunāz, 2012), p. 22.
47 Abid

${ }^{48}$ J. U. Al-Qāid, Dirāsah Al-Tablīliyyah li Syahsyiyati Al-Rasūl (Beirut: Dār Al-Nafāis, 2014), p. 238-241.

${ }^{49}$ M. Rawwās, Dirāsah Al-Tabliliyyah li Syabsyiyati AlRasūl min Hilāl Siratihi Al-Syarîfah (Beirut: Dār Al-Nafāis., 1988), p. 240.

${ }^{50}$ Rawwās. 
The social reality now has been narrowed down to the "media reality." 51 The media has the power to change people's perspective, opinion and attitudes. Ultimately, it has the power to transform society. ${ }^{52}$ This tendency of narrowing meaning, as well as the phenomena of shared consciousness, adds to the responsibility of social media. Mass media as an environmental factor changes audiences' behavior through the classical process, the prevalent role or imitation process (social learning). ${ }^{53}$ Rakhmat argues that the media tiday is not a spectacle is a factor that determines people's opinion and action in life. ${ }^{54}$ The danger of the media now is how it can be used as a public instrument for the mobilization of people through preaching that tends to favor the dominant groups in society. ${ }^{55}$ In consuming media, the consumer must be careful; the news sources must be clear; and the news must be factually correct. ${ }^{56}$ The wise attitude is to filter the information and cross-checking that facts before sharing.
Internalization of the Value of Islam Rahmatan lil Alamin through the Media

Internalization is the planting, forming, or including of a set of values into oneself. ${ }^{57}$ This is in line with Tafseer who has a crush that internalization is interpreted by putting knowledge and skills into one's personal ${ }^{58}$, can also be said by stating the value in one's self ${ }^{59}$. According to Poerwadarminta ${ }^{60}$ internalization is a passionate acceptance of doctrines or values such that they are manifested regularly in action. ${ }^{61}$

Internalization is an attempt to present something that is originally in the external world to the internal life of a person, resulting in a continuous transformation towards a certain ideal. ${ }^{62}$ Internalization can also be understood as personalization, because it involves the movement from the external realm to the internal realm. It is also said to be personalized because the effort allows the knowledge and skills to merge with himself. ${ }^{63}$

Value is a driving force in life, which gives meaning and validity to actions. ${ }^{64}$ Values allows someone to act based on their free choice. ${ }^{65}$ According to Rockeach, "value is an enduring belief that a specific mode of conduct or endstate of existence is personally or socially preferable to an opposite or converse mode of

51 I. Jafar, 'Konsep Berita dalam Al-Qur'an (Implikasinya dalam Sistem Pemberitaan di Media Sosial)', Jurnalisa, 3.1 (2017), 1-15.

${ }^{2}$ N. Islam, 'Media Massa Sebagai Sarana Dakwah Yang Strategis dalam Kontra Terorisme Media Barat dan Yahudi', Jurnal Ilmu Dakwah dan Pengembangan Komunitas, 10.1 (2015), 57-88.

53 Mokhamad Abdul Aziz, 'Media Massa Islam dalam Tatangan Global (Analisis Dakwah dan Cyber Media di Indonesia)', Islamic Communication Journal, 2.2 (2018), 200-218 <https://doi.org/10.21580/icj.2017.2.2.2169>.

54 J. Rakhmat, Psikologi Komunikasi (Bandung: PT Remaja Rosdakarya, 1988), p. 32.

55 A. Muttaqin, 'Agama dalam Representasi Ideologi Media Massa', Komunika: Jurnal Dakwah \& Komunikasi, 6.2 (2015), p. 1-9.

${ }^{56}$ Jafar.

57 Syihabuddin., Pendidikan dan Bahasa dalam Persepektif Islam (Bandung: Rizqi Pres, 2011), p. 15-18.

58 Ahmad Tafsir, Metodologi Pengajaran Agama Islam. (Bandung: PT. Remaja Rosda Karya, 2010), p.124-126.

${ }^{59}$ Lukis Alam, 'Internalisasi Nilai-Nilai Pendidikan Islam dalam Perguruan Tinggi Umum Melalui Lembaga
Dakwah Kampus', Istawa: Jurnal Pendidikan Islam, 1.2 (2016), $101-20$ <https://doi.org/10.24269/ijpi.v1i2.171>.

60 W.J.S Poerwadarminta, Kamus Umum Bahasa Indonesia (Jakarta: Balai Pustaka, 2002) p. 439.

${ }^{61}$ Herbert C. Kelman, 'Compliance, Identification, and Internalization Three Processes of Attitude Change', Journal of Conflict Resolution, 6.1 (1958), 185-214 <https://doi.org/10.1177/002200275800200106>.

62 Muhamad Parhan and Bambang Sutedja, 'Penerapan Pendekatan Pembelajaran Kontekstual dalam Pendidikan Agama Islam di Universitas Pendidikan Indonesia', TARBAWY: Indonesian Journal of Islamic Education, $\quad 6.2 \quad$ (2019), $114-126$ <https://doi.org/10.17509/t.v6i2.20165>.

${ }^{63}$ Kama Abdul Hakam, 'Internalisasi Pendidikan Karakter di Sekolah Dasar', Paper, Disampaikan dalam Seminar Nasional di Universitas Indonesia Tahun 2015.

64 Et.al. Afifuddin, Administrasi Pendidikan

(Bandung: CV. Insani Mandiri, 2005) p. 17.

65 Sopyan Sauri, Pendidikan Karakter dalam Perspektif Islam (Bandung: Rizqi Press, 2012) p. 17. 
conduct or end-state of existence." ${ }^{96}$ While Feather (1994) suggests that: "value is a general belief about desirable or undesirable ways of behaving and about desirable or undesirable goals or end-states." ${ }^{97}$ The values that are believed to be the truth will eventually form a value system that can affect a whole community. Who can influence which of these individuals are taken in the society, where the choice can give consequences for those who choose it. Good choices lead to reward, while bad choices lead to punishment.

Islam rahmatan lil alamin to understand Islam as a faith that gives peace and spread the value of compassion to the entire world. ${ }^{68}$ Rahmatan lil alamin Consists of two syllables "rabmatan" (loving and caring) and "alamin" (all nature and its contents) ${ }^{69}$, this means that the Islamic teachings are universal, not only addressed to groups or countries but all mankind, nature and all its contents ${ }^{70}$. Therefore, the value of Islam should be able to play its role dynamically ${ }^{71}$ by advancing several principles: maintaining harmony, peace, mutual respect, and liberation (liberation), not as domestication, social (social and cultural domestication) ${ }^{72}$.

Islam as rahmatan lil alamin is the expression of Islamic teachings that upholds truth, enacting the good and encouraging progress. ${ }^{73}$ It is oriented towards human personal development to strengthen respect for human rights and fundamental freedoms and the need for mutual understanding, tolerance, and friendship between nations, races, and religious groups in order to preserve peace. ${ }^{74}$ Furthermore, Islam rahmatan lil alamin teaches human normative values, such as justice, honesty, equality, freedom, fraternity, and deliberation. It aims to create the best community life through sustainable living and by internalizing the value of solidarity and cooperation between people, who understand plurality and oppose exclusivism and homogeneity. ${ }^{75}$

Islam rabmatan lil alamin is a commitment to uphold humanity's values and teach social empathy, so that individuals and social groups are assured of their rights as independent and dignified human beings. This is done by promoting a tolerant attitude based on the spirit of affection towards others. The mission of Islam rabmatan lil alamin is to be a bearer of mercy for the entire world. This means that Islam will liberate mankind from all forms of anarchy and injustice.

Islam teaches the faithful to act without prejudice against people; however, this is distorted by extremist understanding of the religion. It is this distorted picture that is displayed and propagated in the anti-Islamic media, thus causing Islamophobia. This perspective gives a false and incomplete understanding of Islam. This must be countered by a thorough, factual, and balanced understanding of the concept of Islam rabmatan lil alamin through the media. The media can be used as a means of spreading the true teachings and values of Islam (da'wab). The media must be
${ }^{66}$ M Rokeach, The Nature of Human Value (New York: The Free Press, 1973) p. 5.

${ }^{67}$ N. T. Feather, 'Values, National Identification and Favouritism', Towards the In-group, 33.4 (1994), 467476.

68 Jamal Mamur Asmani, 'Rekonstruksi Teologi Radikalisme di Indonesia, Menuju Islam Rahmatan lil Alamin', Wahana Akademika: Jurnal Studi Islam dan Sosial, 4.1 (2017), $1-17$

<https://doi.org/10.21580/wa.v4i1.1475>.

69 Z. Syahnasyah, 'Telaah Nilai Kemanusiaan dan Perdamaian dalam Perspektif Rahmatan lil Alamin',
Journal of Peace Education and Islamic Studies, 1.1 (2018), 114.

${ }^{70}$ Luthfi.

${ }^{71}$ Fauzi.

72 Asril Wahyun, 'Membangun Kesadaran InklusifMultikultural untuk Deradikalisasi Pendidikan Islam', AtTa'lim : Media Informasi Pendidikan Islam, 2.1 (2017), 13042

${ }^{73}$ Mucharomah.

${ }^{74}$ M. N. I. Saleh, Peace Education, Kajian Sejarah, Konsep dan Relevansinya dengan Pendidikan Islam (Yogyakarta: AR-RUZZ Media, 2012), p. 65.

75 W. Montgomery, Islamic Political Thought (Edinburgh: Edinburgh University Press, 1968), p. 94. 
neutral in presenting the social, ritual and theological aspects of Islam. The media must reflect, appreciate, and transform moral values in a social reality where Muslims and nonMuslims coexist. By doing this, the media can create peace, justice, compassion, and harmony. ${ }^{76}$

The fundamental principle of media intervention in internalizing the values of Islam rabmatan lil alamin is to promote the principles of ukhuwah Islamiyah, i.e. Islamic fraternity or social solidarity; ukhuwah wathaniyah, a fraternal bond based on national kinship; and ukbuwah basyariyah, which is a fraternal bond based on universal humanity. ${ }^{77}$ These principles must always be held firmly in countering the negative image of Islam.

The ideas, notions, and tenets of Islam rabmatan lil alamin must be conveyed through the media, because the media is a tool that has a great influence on people's interaction. ${ }^{78}$ Propaganda about Islamophobia through the media can be solved by the presentation of Islam rabmatan lil alamin. This can be achieved by conveying true Islamic teachings to the world, and by conveying positive aspects of Muslim life around the world. ${ }^{79}$

The role of the media must be based upon principles that are supported with data, facts, and clear evidence. Doing this allows for a deeper understanding of Islam and the values of Komfrehensip that it teaches. This will make people unite instead of dispersing on account of news that are based on assumptions, suppositions, and hoaxes. The media in Islam should serve as an educator (muaddib) on the teachings of Islam that rahmatan lil alamin; as the agent of correct information (musaddid) that resists all forms of distorted news; as a reformer (mujaddid) of Islamic understanding and teachings; as a unifying force (munvabbid) for all people around the world; and as fighters (mujabid) who struggles and works hard to provide the correct the information on Islam in the effort of presenting Islam rabmatan lil alamin $^{80}$ based on the principle of amar ma'ruf nabi munkar (i.e., calling unto good and prohibiting evil or wrong doing) by not muting the situation and righteousness for the benefit of the individual, or social groups. ${ }^{81}$

\section{Conclusion}

The Islamophobia propaganda has presented erroneous information about Islam; this has resulted the damaging reputation of Islam in the eyes of the world that has led to discrimination and racism against Muslims. This can be solved by presenting information about true Islamic teachings, namely Islam rahmatan lil alamin, which is based on the idea of compassion for the entire world. This conception of Islam is one that is concerned with upholding the values of humanity and teaching social sensitivity, empathy, and guaranteeing human rights and humanity. These values can be propagated by the media. The media has become a site of a war of opinions between invested parties, who could direct public opinion. The media was chosen to internalize the value of Islam rahmatan lil alamin because it is a technology that can reach a wide audience. Thus is is capable of disseminating information quickly, broadly, and continuously. The media is not only a spectacle, but also a source of guidance. Through it, the recipient of the information can reflect, appreciate, and transform the values conveyed to create tolerance in society, one that leads to peace,

76 Zuhdi.

77 Rasyid.

78 M. Pitchan, M. A., Rahman, S. N. H., Kasim, 'Teori Al-Daruriyyat dan Penggunaan Media Sosial: Satu Perbincangan Konsep', Jurnal Komunikasi Malaysian Journal of Communication, 34.4 (2018), 75-92.

79 M. Zakariya, N., Darda, Media sebagai Wasilah Dakwah,' Al-Hikmah, 5.5 (2013), 92-99.
80 Abu Hasan Hasbullah, Teknologi Makin Maju, Pemikiran Makin Mundur (Selangor: Utusan Karya, 2012), p. 21.

81 Zulkiple bin Abd Ghani, 'Komunikasi Islam sebagai Komunikasi Alternatif, Islamiyyat, 22. 1 (2001), 79-89. 
justice, compassion, and harmony among all human beings in the world.

\section{References}

\section{Books}

Abid, Z., Al-Istid'àf wa Ahkāmubu fì Al-Fiqh AlIslāmi (Riyādh: Dār Kunāz, 2012)

Afifuddin, Et.al., Administrasi Pendidikan (Bandung: CV. Insani Mandiri, 2005)

Ahmad Tafsir, Metodologi Pengajaran Agama Islam. (Bandung: PT. Remaja Rosda Karya, 2010)

Al-Fahdāwī, Khālid bin Sulaimān, Al-Figh AlSiyäsi li Al-Watsäiq Al-Nabawiyyah (Urdun: Dār Al-Ammār, 1995)

Al-Qāid, J. U., Dirāsah Al-Tabliliyyah li Syahsyizati Al-Rasūl (Beirut: Dār Al-Nafāis, 2014)

Eriyanto., Analisis Wacana, Pengantar Analisis Teks Media (Yogyakarta: LKIS, 2005)

Geisser, V., La Nowvelle Islamophobie (Paris: La Découver, 2003)

Hasbullah, Abu Hasan, Teknologi Makin Maju, Pemikiran Makin Mundur (Selangor: Utusan Karya, 2012)

Ibrahim, T., Perkembangan Islam di Tiongkok (Jakarta: Bulan Bintang, 1979)

Kurniawan, N., Nasib Etnis Minoritas Robingya (Kuala Lumpur: Pusat Informasi dan Advokasi Rohingya, 2012)

Kuswaya, A., Melawan Islamophobia Penerapan Tema Qurani Tentang Wasathiyyah Kasus di Maroko dan Indonesia (Jawa Tengah: Kekata Grup, 2020)

Levinson, D., Ethnic Relations: A Cross Cultural Encyclopedia (Santa Barbara: ABC-CLIO Inc, 1994)

Mahamdallie, H., Islamophobia: The Othering of Europe's Muslims (UK: Cambridge University Press, 2015)

Modood, T., 'Difference', Cultural Racism and Anti-Racism', in P. Werbner and 'T. Modood (Eds), Debating Cultural Hybridity: Multi-Cultural Identities and the Politics of AntiRacism, London and Atlantic Highlands (NJ: Zed Books, 1997)

Montgomery, W., Islamic Political Thought
(Edinburgh: Edinburgh University Press, 1968)

Poerwadarminta, W.J.S, Kamus Umum Bahasa Indonesia (Jakarta: Balai Pustaka, 2002)

Pramono, A., Peran UNHCR dalam Menangani Pengungsi Myanmar Etnis Robingya di Bangladesh (Periode 1978 -2002) (Jakarta: Universitas Indonesia., 2010)

Rakhmat, J., Psikologi Komunikasi (Bandung: PT Remaja Rosdakarya, 1988)

Rawwās, M., Dirāsah Al-Tabliliyyah li Syahsyiyati Al-Rasūl min Hiläl Siratibi Al-Syarifah (Beirut: Dār Al-Nafāis, 1988)

Rokeach, M, The Nature of Human Value (New York: The Free Press, 1973)

Sauri, Sopyan, Pendidikan Karakter dalam Perspektif Islam (Bandung: Rizqi Press, 2012)

Saleh, M. N. I., Peace Education, Kajian Sejarah, Konsep dan Relevansinya dengan Pendidikan Islam (Yogyakarta: AR-RUZZ Media, 2012)

Syihabuddin., Pendidikan dan Bahasa dalam Persepektif Islam (Bandung: Rizqi Pres, 2011)

Wilkins, Luqman Hakeem Frank, Pragathesh Batumalai, and Kamarul Azmi Jasmi, 'Media Sosial dan Dampak Positif Menurut Islam', Prosiding Seminar Sains Teknologi dan Manusia 2019

Zawacki, Benjamin, 'Amnesty: Muslim Rohingya Terus Alami Kekerasan', Report (Jakarta, 2012 $<$ https://www.bbc.com/indonesia/dunia /2012/07/120720_burma_new>

\section{Journals}

A'dawiyah, Ismail, 'Konsep Keluarga Berkualiti Menurut Islam', Al-Hikmah, (2011), 121 44

Alam, Lukis, 'Internalisasi Nilai-Nilai Pendidikan Islam dalam Perguruan Tinggi Umum Melalui Lembaga Dakwah Kampus', Istawa: Jurnal Pendidikan Islam, $1.2 \quad$ (2016), 101-20 $<$ https://doi.org/10.24269/ijpi.v1i2.171 $>$ 
Asmani, Jamal Mamur, 'Rekonstruksi Teologi Radikalisme di Indonesia, Menuju Islam Rahmatan lil Alamin', Wahana Akademika: Jurnal Studi Islam dan Sosial, 4.1 (2017), 117

<https://doi.org/10.21580/wa.v4i1.1475 $>$

Aziz, Mokhamad Abdul, 'Media Massa Islam dalam Tatangan Global (Analisis Dakwah dan Cyber Media di Indonesia)', Islamic Communication Journal, 2.2 (2018), 200-218 $<$ https://doi.org/10.21580/icj.2017.2.2.2 $169>$

Dakir, Hajah Jawiah, '[Ms] Asas Pembentukan Keluarga Menurut Perspektif Al-Quran dan Al-Sunnah', Islamiyyat: Jurnal Antarabangsa Pengajian Islam; International Journal of Islamic Studies, 17 (1996), 3-18

Erik, B., 'Defining and Researching Islamophobia.', Middle East Studies Association of North America (MESA) Is Collaborating with JSTOR to Digitize, Preserve and Extend Access to Review of Middle East Studies, $\quad 46.2 \quad$ (2012), 180-89 $<$ https://doi.org/https://doi.org/10.101 7/s0026318400054146>

Fauzi, Ahmad, 'Konstruksi Pendidikan Islam Berbasis Rahmatan Lil'alamin; Suatu Telaah Diskursif, At- Ta'lim: Jurnal Pendidikan, $4.2 \quad$ (2018), 122-39 $<$ https://doi.org/10.36835/attalim.v4i2.5 $8>$

Feather, N. T., 'Values, National Identification and Favouritism', Towards the In-group, 33.4 (1994), 467-476

Ghani, Zulkiple bin Abd, 'Komunikasi Islam sebagai Komunikasi Alternatif, Islamiyyat, 22. 1 (2001), 79-89

Islam, N., 'Media Massa Sebagai Sarana Dakwah Yang Strategis dalam Kontra Terorisme Media Barat dan Yahudi', Jurnal Ilmu Dakwah dan Pengembangan Komunitas, 10.1 (2015), 57-88

Ismatulloh, A M, 'Metode Dakwah dalam AlQur'an (Studi Penafsiran Hamka Terhadap QS. An-Nahl: 125)', Lentera, IXX.2 (2015), 155-69 $<$ https://doi.org/http://dx.doi.org/10.2 1093/lj.v17i2.438>
Jād, N. M., Al-Ta'āmul ma'a ghair Al-Muslimin fi Al-'Abdi Al-Nabawì (Cairo: Dār alMaymān, th)

Jafar, I., 'Konsep Berita dalam Al-Qur'an (Implikasinya dalam Sistem Pemberitaan di Media Sosial)', Jurnalisa, 3.1 (2017), 1-15

Kelman, Herbert C., 'Compliance, Identification, and Internalization Three Processes of Attitude Change', Journal of Conflict Resolution, 6.1 (1958), 185-214 <https://doi.org/10.1177/002200275800 200106>

López, Fernando Bravo, 'Towards a Definition of Islamophobia: Approximations of the Early Twentieth Century', Ethnic and Racial Studies, $34.4 \quad$ (2011), 556-73 <https://doi.org/10.1080/01419870.201 $0.528440>$

Luthfi, Khabibi Muhammad, 'Islam Nusantara: Relasi Islam dan Budaya Lokal', Shabih: Journal of Islamicate Multidisciplinary, 1.1 (2017), 1-18 $<$ https://doi.org/10.22515/shahih.v1i1.5 $3>$

Marranci, Gabriele, 'Multiculturalism, Islam and the Clash of Civilisations Theory: Rethinking Islamophobia', Culture and Religion, 5.1 (2004), 105-17 <https://doi.org/10.1080/014383004200 0200373>

Masduqi, Irwan, 'Deradikalisasi Pendidikan Islam Berbasis Khazanah Pesantren', Jurnal Pendidikan Islam, 2.1 (2013), 1-20 <https://doi.org/10.14421/jpi.2013.21.1 $-20>$

Moordiningsih, 'Islamophobia dan Strategi Mengatasinya', Buletin Psikologi, 12.2 (2015), $\quad$ 73-84 <https://doi.org/10.22146/bpsi.7470>

Mucharomah, Miftah, 'Guru di Era Milenial dalam Bingkai Rahmatan lil Alamin', Edukasia Islamika, 2.2 (2017), 172 $<$ https://doi.org/10.28918/jei.v2i2.1667 $>$

Muttaqin, A., 'Agama dalam Representasi Ideologi Media Massa', Komunika: Jurnal Dakwah \& Komunikasi, 6.2 (2015)

Nasuha, C, 'Konsep Islam dalam Pemikiran 
ISIF', Jurnal Islam Indonesia, 1, 1 (2009), 1-8

Nur Zahidah, Jaapar, and Azahari Raihanah, 'Model Keluarga Bahagia Menurut Islam', Jurnal of Fiqh, 8.2 (2011), 20

Parhan, Muhamad, Aiman Faiz, Abdul Karim, Risris Hari Nugraha, Ganjar Eka Subakti, Mohammad Rindu Fajar Islamy, and others, 'Internalization Values of Islamic Education at University', International Journal of Psychosocial Rebabilitation, 24.8 (2020), 14778-91 $<$ https://doi.org/10.37200/IJPR/V24I8 /PR281455>

Parhan, Muhamad, and Bambang Sutedja, 'Penerapan Pendekatan Pembelajaran Kontekstual dalam Pendidikan Agama Islam di Universitas Pendidikan Indonesia', Tarbawy: Indonesian Journal of Islamic Education, 6.2 (2019), 114-126 <https://doi.org/10.17509/t.v6i2.20165 $>$

Pitchan, M. A., Rahman, S. N. H., Kasim, M., 'Teori Al-Daruriyyat dan Penggunaan Media Sosial: Satu Perbincangan Konsep', Jurnal Komunikasi Malaysian Journal of Communication, 34.4 (2018), 75-92

Pradipta, C, P., 'Pengaruh Islamophobia Terhadap Peningkatan Kekerasan Muslim di Perancis', Global \& Policy, 4.2 (2016), 101-14

Rachman, Rio Febriannur, 'Perspektif Karen Armstrong Tentang Islamofobia di Media Barat', Dakwatuna: Jurnal Dakwah dan Komunikasi Islam, $4.2 \quad$ (2018) $<$ https://doi.org/10.36835/dakwatuna.v $4 \mathrm{i} 2.306>$

Rana, Junaid, 'The Story of Islamophobia', Souls, 9.2 (2007), 148-61 <https://doi.org/10.1080/109999407013 82607>

Rasyid, Muhammad Makmun, 'Islam Rahmatan lil Alamin Perspektif KH. Hasyim Muzadi', Epistemé: Jurnal Pengembangan Ilmu Keislaman, 11.1 (2016), 93-116 <https://doi.org/10.21274/epis.2016.11. 1.93-116>

Runnymede, T ., 'Islamophobia: A Challenge for Us All. London United Kingdom',
British Library Document Supply Centre, 1997

Ruthven, M, 'Islam in the Media. In Interpreting Islam', Sage: In Interpreting Islam, 2012, 51-75 <https://doi.org/https://doi.org/10.413 5/9781446217467.n4;>

Stolzjörg, 'Explaining Islamophobia. A Test of Four Theories Based on the Case of a Swiss City', Swiss Journal of Sociology, 31.3 (2005), 547-661

Syahnasyah, Z., 'Telaah Nilai Kemanusiaan dan Perdamaian dalam Perspektif Rahmatan lil Alamin', Journal of Peace Education and Islamic Studies, 1.1 (2018), 1-14

Turmudi, Muhammad, 'Produksi dalam Perspektif Ekonomi Islam', Islamadina, XVI (2017), 37-56

Wahyun, Asril, 'Membangun Kesadaran Inklusif-Multikultural Untuk Deradikalisasi Pendidikan Islam', AtTa'lim : Media Informasi Pendidikan Islam, 2.1 (2017), 130-42

Zainudin, 'Kajian Tentang Toleransi Beragama dalam Surat Al-Kafirun', Jurnal Dakwah, X.1 (2009), 19-31

Zakariya, N., Darda, M., 'Media sebagai Wasilab Dakwah', Al-Hikmah, 5.5 (2013), 92-99

Zuhdi, Muhammad Harfin, 'Visi Islam Rahmatan lil 'Alamin: Dialektika Islam dan Peradaban', Akademika Jurnal Pemikiran Islam, $53.9 \quad$ (2017), 149-70 <https://doi.org/doi.org/10.1017/CBO 9781107415324.004>

S Zúquete, J. P., 'The European Extreme-Right and Islam: New Directions?', Journal of Political Ideologies, 13.3 (2008), 321-44

\section{Paper}

Abdel, H. Z., 'Islamophobia...A Threat....A Challenge', Paper, Published on International Conference on Muslim and Islam in 21 st Century: Image and Reality, Kualalumpur, International Islamic University of Malaysia, 2004

Hakam, Kama Abdul, 'Internalisasi Pendidikan Karakter di Sekolah Dasar', Paper, Disampaikan dalam Seminar Nasional di Universitas Indonesia Tahun 2015 